\title{
STUDIES ON THE MECHANISM OF ACETATE OXIDATION BY BACTERIA
}

\author{
V. Evidence for the Participation of Fumarate, Malate, and \\ Oxalacetate in the Oxidation of Acetic Acm by \\ ESCHERICHIA COLI
}

By SAMUEL J. AJL

(From the Department of Bacteriology and Immunology, Washingion University School of Medicine, St. Louis)

(Received for publication, January 12, 1951)

In a previous publication (1) evidence was presented implicating succinate and pyruvate quantitatively in the oxidative breakdown of acetic acid to $\mathrm{CO}_{2}$ and water by acetate-adapted strains of Escherichia coli, while $\alpha$-ketoglutaric acid was eliminated as a possible intermediate. In addition, fumarate, malate, and oxalacetate have also been shown, qualitatively at least, to participate as intermediates in the oxidation of the $\mathrm{C}_{2}$ fatty acid. However, the occurrence of an unexpected side reaction, involving appreciable reduction of $\mathrm{C}_{4}$-dicarboxylic acid products of succinate oxidation back to succinate, complicated the interpretations of most experiments performed using carrier malate, fumarate, or oxalacetate.

In this paper detailed data are presented which were obtained when $2-\mathrm{C}^{14}$ acetate was incubated in the presence of fumarate, malate, oxalacetate, and $\alpha$-ketoglutarate. Further, conditions will be described which reduce the unexpected reduction of the above mentioned $\mathrm{C}_{4}$-dicarboxylic acids back to succinate. From chemical analysis of the residual acids, $\mathrm{CO}_{2}$, and cell material, it was possible to show that when an appreciable fraction of acetate, as well as other substrates, was metabolized under high oxygen tension, there were incorporation and distribution of labeled carbon into fumarate and malate in the amount to be expected on the basis of a Thunberg-Knoop condensation cycle, whereas there was no comparable incorporation into $\alpha$-ketoglutarate. These results plus those already published $(1,2)$ appear to exclude a tricarboxylic acid cycle as a major pathway for acetate oxidation in $E$. coli.

\section{Methods and Materials}

The same strain of Escherichia coli (E26) was used in these experiments as in the previous work. For all experiments cells were grown with constant aeration at $30^{\circ} \mathrm{C}$. in a medium containing 1.5 per cent anhydrous sodium acetate, 0.4 per cent ammonium sulfate, 0.8 per cent $\mathrm{KH}_{2} \mathrm{PO}_{4}, 0.07$ per cent tryptone, and 20 per cent tap water (for 
inorganic ions), at an initial $\mathrm{pH}$ of 7.0 for 48 hours, unless otherwise indicated. They were then centrifuged free of growth medium, aerated for several hours in phosphat $\epsilon$ buffer ( $\mathrm{pH}$ 7.0) to reduce endogenous activity, and either used immediately or stored in the ice box. Such cells remained active on the substrates employed for a number of weeks, if kept at about $5^{\circ} \mathrm{C}$.

The basic experimental procedure followed was to incubate methyl-labeled acetate in the presence of various concentrations of one or two intermediates considered to be involved in the oxidative breakdown of the $\mathrm{C}_{2}$ acid.

Respiration was measured in $30 \mathrm{ml}$. Warburg vessels. The rate of $\mathrm{O}_{2}$ uptake was determined at $30^{\circ} \mathrm{C}$. with $\mathrm{NaOH}$ in the center well to absorb $\mathrm{CO}_{2}$. At the end of the incubation period, the reaction mixture was acidified and the additional $\mathrm{CO}_{2}$ caught in alkali. The gas was ultimately precipitated as the barium salt and the radioactivity measured.

The isolation and degradation procedures for succinate, fumarate, malate, and oxalacetate have been described by Ajl and Kamen (1). Some modifications, however, in the separation procedures of succinate, fumarate, and malate were introduced. Immediately after incubation the reaction mixture was acidified and the cells removed by centrifugation. The supernatant was steam-distilled to remove residual acetate and the non-volatile material ether-extracted. The ether-soluble portion was then taken up in a small volume of water and chromatographed according to the procedures described by Lugg and Overell (3). The bands corresponding to succinate, fumarate, or malate were eluted with water and quantitatively determined; malate by the method of Korkes and Ochoa (4); fumarate by the method of Harrison (5); succinate by the conventional beef heart succinoxidase preparation.

All radioassays were made using a conventional end window $\mathrm{G}-\mathrm{M}$ tube connected to a Tracerlab autoscaler. Solutions were pipetted on recessed stainless steel discs after neutralization. Solids, such as cells and $\mathrm{BaCO}_{3}$, were slurried in ethyl alcohol and plated evenly on discs. Drying was conducted under an infrared lamp. Appropriate corrections for self-absorption and carbon content were applied.

\section{EXPERMMENTAL RESULTS}

In a preliminary experiment, simultaneous oxidation of labeled acetate, unlabeled fumarate, and $\alpha$-ketogiutarate was studied. The results are exhibited in Table $I$. It is seen that despite the disappearance of practically all fumarate carrier, no corresponding accumulation of acetate occurred, as usually observed when succinate carrier was used (1). Instead there appeared a surprisingly large quantity of succinate arising apparently from reduction of fumarate by endogenous $H$ donors and/or hydrogen from the oxidation of acetate. The latter source of hydrogen could not have accounted for most of this reduction as seen from the total amount of acetate disappearing. The major source of hydrogen must have been endogenous cell material. This result was most unexpected considering that the experiment was conducted in air. Krebs (6) showed that a fermentative dismutation of fumarate occurred in $B$. coli under anaerobic conditions, in which 7 molecules of fumarate produced 6 molecules 
of succinate besides 4 molecules of carbonate. It is possible that a similar reaction occurred in this experiment, owing to the denseness of the cell suspensions used, which may have resulted in maintaining many of the cells in what amounted to an anaerobic state. However, sufficient oxidation of acetate and fumarate, as well as succinate and $\alpha$-ketoglutarate, occurred to result in a

TABLE I

Data on the Oxidation of 2-C $C^{4}$-Acetate in the Presence of Small Concentrations of Inactive Fumarate and $\alpha$-Ketoglutarate by Escherichia coli

\begin{tabular}{|c|c|c|c|c|c|c|c|c|c|}
\hline \multirow{2}{*}{ Fraction } & \multicolumn{2}{|c|}{ Chemical data } & \multicolumn{2}{|c|}{ Total counts } & \multicolumn{2}{|c|}{ Specific activity } & \multirow{2}{*}{$\begin{array}{l}\text { Average } \\
\text { specific } \\
\text { activity }\end{array}$} & \multicolumn{2}{|c|}{$\begin{array}{c}\text { Manometric } \\
\text { data oxygen } \\
\text { uptake }\end{array}$} \\
\hline & Initial & Final & Initial & Final & Initial & Final & & $\begin{array}{l}\text { Experi- } \\
\text { mentsl }\end{array}$ & $\begin{array}{l}\text { Endog. } \\
\text { enous }\end{array}$ \\
\hline & $\mu \mathrm{M}$ & $\mu \mathrm{M}$ & C.P.M. & C.P.M. & $\begin{array}{c}\text { C.P.M. } \\
\text { PER } \mu \mathrm{M}\end{array}$ & $\begin{array}{c}\text { C.P.X. } \\
\text { PER } \mu \mathrm{M}\end{array}$ & $\begin{array}{c}\text { C.P.M. } \\
\text { PER } \mu \mathrm{MI}\end{array}$ & $\mu \mathrm{ll}$. & $\mu l$. \\
\hline Acetate... . & 100 & 44 & 114,000 & 38,000 & 1140 & 870 & 1005 & 4240 & 990 \\
\hline$\alpha$-Ketoglutarate.. . . & 125 & 103 & $\mathbf{0}$ & $<220$ & $<2$ & & & & \\
\hline Fumarate..... & 125 & $\begin{array}{l}\text { Approx. } \\
30^{*}\end{array}$ & 0 & $7,000^{*}$ & 0 & $230^{*}$ & & & \\
\hline Succinate......... & 0 & 104 & 0 & 24,000 & 0 & 232 & & & \\
\hline $\mathrm{COO}^{-}$groups...... & & & & $\begin{array}{l}12,000 \\
\text { (uni- } \\
\text { form } \\
\text { distri- } \\
\text { bution } \\
\text { as- } \\
\text { sumed) }\end{array}$ & & 58 & 29 & $\begin{array}{r}\text { Calcu } \\
\text { fron } \\
\text { sub } \\
\text { stra } \\
\text { disa } \\
\text { pea } \\
4400\end{array}$ & $\begin{array}{l}\text { lated } \\
\text { m } \\
\text { ates } \\
\text { ap- } \\
\text { red } \\
\mu l .\end{array}$ \\
\hline Cells . & & & 0 & 8,600 & & & & & \\
\hline Carbonate... & & & 0 & 3,300 & & & & & \\
\hline
\end{tabular}

The complete system consisted of $1 \mathrm{ml}$. of $0.2 \mathrm{M}$ phosphate buffer, $\mathrm{pH} 7.0,1 \mathrm{ml}$. of a 20 per cent suspension of 20 day old acetate-grown $E$. coli; substrates as indicated and $\mathrm{NaOH}$ in center well. Total volume $11 \mathrm{ml}$. Temperature $30^{\circ} \mathrm{C}$. Time of incubation 5 hours. Gas phase: air.

Recovery data: residual acetate 38,300 ; succinate 24,000 ; fumarate 7,000 ; cells 8,600 ; carbonate 3,300. Total 81,200 counts. Initial 114,000 counts. Recovery 71 per cent.

* See text.

distribution of $\mathrm{C}^{14}$ almost identical with a succinate- $\alpha$-ketoglutarate carrier experiment (1).

The data were analyzed in the same manner as given for succinate-trapping experiments (1) with modifications introduced by uncertainties occasioned by the complicating factor of the fumarate transformation to succinate. From the $\mathrm{C}^{14}$ content of 24,000 c.P.M. in final succinate and average specific $\mathrm{C}^{14}$ content of acetate (1005 C.P.M.), it could be estimated that about $24 \mu \mathrm{M}$ acetate were trapped forming $12 \mu \mathrm{M}$ succinate. At the same time $22 \mu \mathrm{M} \alpha$-ketoglutarate 
disappeared, forming succinate. Assuming no succinate utilization, at least 46 $\mu \mathrm{M}$ of succinate arose from fumarate. Another $24 \mu \mathrm{M}$ of fumarate could have been transformed to succinate by hydrogen transfer from acetate. The chemical method of fumarate analysis was not adequate to fix the residual fumarate content accurately and at best it could only be estimated to lie between 10 and $30 \mu \mathrm{M}$. Hence, as little as $25 \mu \mathrm{M}$ and as much as $45 \mu \mathrm{M}$ fumarate could have been oxidized to acetate.

It is of interest to note that, after subtraction of $8 \mu \mathrm{Mr}$ estimated as assimilated from $\mathrm{C}^{14}$ content of the cells, $48 \mu \mathrm{M}$ acetate disappeared which was exactly twice the amount condensed, in accordance with the cycling mechanism through succinate.

Assuming uniform distribution of $\mathrm{C}^{14}$ the average activity of succinate carboxyl was 29 C.P.M. per $\mu$ M. Assuming the type of distribution found previously for similar quantities of succinate carrier (1), the average $\mathrm{C}^{14}$ content of succinyl carboxyl was about 21 c.P.M. per $\mu$ M. The average specific activity of the $\mathrm{CO}_{2}$ evolved was 13 C.P.M. per $\mu \mathrm{M}$ which, under the circumstances, was adequate agreement with the postulate that succinyl carboxyl was the precursor of $\mathrm{CO}_{2}$ in acetate oxidation.

The acetate dilution observed was somewhat less than that expected on the basis of the above estimates of fumarate and succinate utilization. The observed final $\mathrm{C}^{14}$ content of acetate was 870 c.P.M. per $\mu \mathrm{M}$, whereas only 730 C.P.M. per $\mu \mathrm{M}$ was expected as a maximal final activity. The expected oxygen uptake on the basis of the above picture was in the neighborhood of $4400 \mu l$. which indicated complete suppression of endogenous $\mathrm{O}_{2}$ uptake, a result in harmony with the small dilution of acetate.

Alternatively one might assume that all fumarate had been converted to succinate. Hence a total of $148 \mu \mathrm{M}$ succinate would have been formed. Then $\sim 40 \mu \mathrm{M}$ succinate would have been oxidized to acetate. Recalculation on this basis leads to very little change in the oxygen uptake estimate, dilution of acetate, or ratio of moles acetate condensed to moles oxidized.

If one were to assume that all acetate which disappeared contributed to succinate formation without uptake of oxygen, the resultant $\mathrm{O}_{2}$ uptake expected would be much too low compared to that actually observed. Other assumptions could be made and tested in this way but none resulted in complete agreement with all data collected, as did the type of process assumed and described in the above calculations.

It is important to note that no appreciable quantity of acetate carbon was trapped in $\alpha$-ketoglutarate, confirming the results reported previously (1).

In Table II, a similar experiment using malate carrier is summarized. The results were practically identical in indicating major entrapment of acetate in succinate. In this case, practically no malate was left at the end of the run, so it could not be ascertained whether any acetate carbon had entered malate added as carrier. 
In summary, both of these experiments confirmed the previously demonstrated condensation of acetate to a $\mathrm{C}_{4}$ acid but not to $\alpha$-ketoglutarate, as well as the cycling mechanism based on $\mathrm{C}_{4}$ acids as intermediates. However, the participation of either malate or fumarate was in doubt because neither remained in appreciable quantity as carrier, having been converted mainly to succinate. It could be shown that, if succinate as precursor were present in

TABLE II

Data on the Oxidation of 2-C14-Acetale in the Presence of Small Concentrations of Inactive Malate and $\alpha$-Ketoghutarate by Escherichia coli

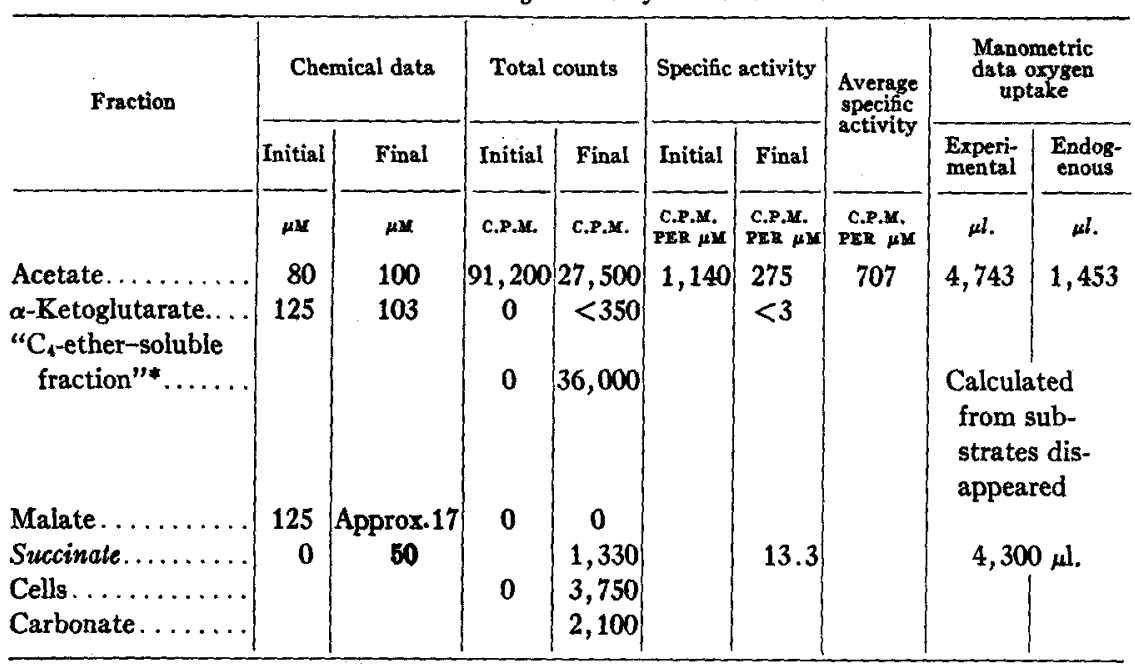

The complete system consisted of $1 \mathrm{ml}$. of 0.2 m phosphate buffer, pH 7.0;1 ml. of a 20 per cent suspension of $\mathbf{2 0}$ day old acetate-grown $E$. coli; substrates as indicated and $\mathrm{NaOH}$ in the center well. Total volume $11 \mathrm{ml}$. Temperature $30^{\circ} \mathrm{C}$. Time of incubation 6 hours.

Recovery data: residual acetate 27,500 ; " $\mathrm{C}_{4}$-ether-soluble fraction" 36,000 ; cells 3750 ; carbonate 2100 . Total 69,350 counts. Initial 91,000 counts. Recovery 76 per cent.

* "C 4 -ether-soluble fraction:" this fraction is obtained after initially steam-distilling off residual acetate, binding keto-acids with bisulfite and extracting with ether for 48 to 72 hours.

any experiment of the relatively short duration of those described in Tables $I$ and II, little activity would have appeared in the malate or fumarate even if they had remained in appreciable quantity, as long as succinate in comparable amounts was present. This followed from the well known time function relating specific activity of precursor to product (7).

An attempt was made, therefore, to minimize the endogenous conversion of fumarate and malate to succinate by using freshly harvested young cells (18 hours). The results with these cells, as shown in Table III, were practically identical with those found for old cells. However, it was possible to demonstrate accumulation of acetate activity in malate and fumarate despite the production 
of succinate as well as to obtain the expected accumulation of acetate. It was also possible to obtain labeled material which could be oxidized to yield appreciable quantities of labeled formate, acetaldehyde, and $\mathrm{CO}_{2}$ without prior dehydrogenation by succinoxidase preparations. The average specific activity

TABLE III

Distribution of Radioactivity in Fumarate or Malate during the Dissimilation of 2-C $C^{14}$-Actate by 18 Hout Old Escherichia coli

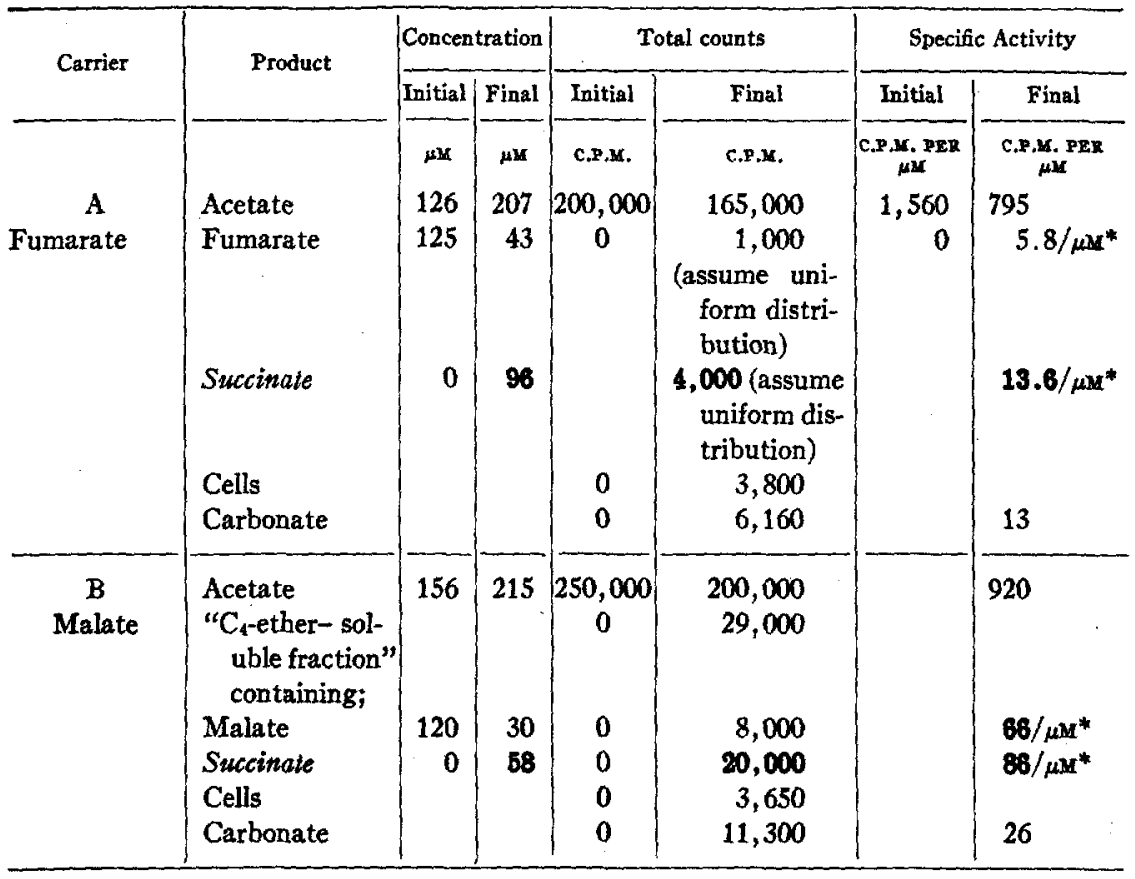

Total volume of reactants $11 \mathrm{ml}$, containing $1 \mathrm{cc}$. of a 10 per cent suspension of freshly harvested (grown for 18 hours) acetate-grown $E$. coli, $1 \mathrm{ml}$. phosphate buffer, $(0.2 \mathrm{M}), \mathrm{pH}$ 7.0 ; substrates as indicated and $\mathrm{NaOH}$ in the center well. Temperature $30^{\circ} \mathrm{C}$. Time of incubation 3 hours.

* $\mu / \mathrm{M}$ of carbon assuming uniform distribution.

of the fumarate and malate was lower than that of succinate formed during the run in agreement with the notion that succinate acted as precursor.

Another experiment was performed based on the assumption that oxalacetate would not be reduced as malate and fumarate were, to succinate. Simultaneous oxidation of unlabeled oxalacetate and labeled acetate yielded results shown in Table IV. Again appreciable succinate formation occurred. In this experiment, however, it was possible to achieve good $\mathrm{C}^{14}$ recovery data as well as reliable assays of initial and final amounts of reactants. From the cellular $\mathrm{C}^{14}$ 
content, it appeared that $\sim 3.3 \mu \mathrm{M}$ acetate were assimilated. A control experiment showed that out of $337 \mu \mathrm{M}$ oxalacetate initially present, $148 \mu \mathrm{M}$ were lost by spontaneous breakdown, so that $189 \mu \mathrm{M}$ were available for cellular activity. $47 \mu \mathrm{M}$ remained at the end of the experiment. At least $64 \mu \mathrm{M}$ were converted to succinate. This left $30 \mu \mathrm{M}$ which were oxidized to acetate. The theoretical $\mathrm{O}_{2}$ uptake was $2600 \mu l$. which compared well with the observed 2580 , provided

TABLE IV

Experiment Using Inactive Oxalacetate as Carrier during the Oxidation of 2-C $C^{14}$-Acelate by Escherichia coli

\begin{tabular}{|c|c|c|c|c|c|c|c|c|c|}
\hline \multirow{2}{*}{ Fraction } & \multicolumn{2}{|c|}{ Chemical data } & \multicolumn{2}{|c|}{ Total counts } & \multicolumn{2}{|c|}{ Specific activity } & \multirow{2}{*}{$\begin{array}{l}\text { Average } \\
\text { specific } \\
\text { activity }\end{array}$} & \multicolumn{2}{|c|}{$\begin{array}{l}\text { Manometric } \\
\text { data } \mathrm{O}_{2} \text { uptake }\end{array}$} \\
\hline & Initial & Final & Initial & Final & Initial & Final & & $\begin{array}{l}\text { Experi- } \\
\text { mental }\end{array}$ & $\begin{array}{l}\text { Endog- } \\
\text { enous }\end{array}$ \\
\hline & $\mu \mathrm{M}$ & $\mu \mathrm{M}$ & C.P.M. & C.P.M. & $\begin{array}{c}\text { C.P.M. } \\
\text { PER } \mu \mathrm{M}\end{array}$ & $\begin{array}{l}\text { C.P.M. } \\
\text { PER } \mu \text {.M }\end{array}$ & $\begin{array}{c}\text { C.P.M. } \\
\text { PER } \mu \mathrm{MM}\end{array}$ & $\mu l$. & $\mu l$. \\
\hline Acetate. . & 126 & 318 & 200,000 & 165,400 & 1,560 & 520 & 1,040 & 2,580 & 1,410 \\
\hline Oxalacetate* & 337 & 47 & 0 & 1,800 & & & & & \\
\hline $\mathrm{COO}^{-}$carbons. . . . & & & 0 & 350 & 0 & 3.7 & & $\begin{array}{l}\text { Calcula } \\
\text { from } \\
\text { strat } \\
\text { appe }\end{array}$ & $\begin{array}{l}\text { ted sub- } \\
\text { es dis- } \\
\text { aringt }\end{array}$ \\
\hline Methylene carbons. & & & & 1,450 & 0 & 15.5 & & 2,60 & $\mu \mathrm{l}$ \\
\hline Succinate......... & 0 & 64 & 0 & 9,000 & & & & & \\
\hline Carbonate.... & & & $\mathbf{0}$ & 2,850 & & 3.7 & & & \\
\hline Cells.... . & & & 0 & 3,330 & & & & & \\
\hline
\end{tabular}

Total volume of reactants $11 \mathrm{ml} .1 \mathrm{ml}$. of a 10 per cent suspension of freshly harvested acetate-grown $E$. coli. $1 \mathrm{ml}$. of $0.2 \mathrm{M}$ phosphate buffer, $\mathrm{pH} 7.0$. Substrates as given in table and $\mathrm{NaOH}$ in center well. Temperature $30^{\circ} \mathrm{C}$. Time of incubation 3 hours.

Recovery data: residual acetate 165,400 ; oxalacetate 1,800 ; succinate 9,000 ; carbonate 2,850 ; cells 3,330 . Total 181,380 counts. Initial 200,000 counts. Recovery 90 per cent.

* Values for oxalacetate are corrected for spontaneous decarboxylation.

$\ddagger$ See text.

endogenous $\mathrm{O}_{2}$ uptake was completely suppressed. This conclusion was again borne out by the finding that the expected acetate dilution from metabolism of oxalacetate alone should have resulted in a final specific activity for acetate of 570 C.P.M. per $\mu \mathrm{Mr}$, whereas the observed value was 520 C.P.M. per $\mu \mathrm{M}$. The amount of acetate condensed to succinate could be estimated to be $\sim 8$ to 9 $\mu \mathrm{M}$. No accurate estimation of acetate oxidation could be made because of the large quantities arising from oxalacetate degradation, but a maximum figure of $\sim 5$ to $10 \mu \mathrm{M}$ was indicated from the $\mathrm{O}_{2}$ uptake data.

An effort to trap the major portion of the acetate carbon in malate and fumarate was made by using relatively large quantities of carrier; i.e., $250 \mu \mathrm{M}$ each of malate and fumarate and aerating the reaction mixture with tank 
oxygen, thus maintaining maximum aerobic conditions. The results are shown in Table V. The major datum in this table is the small concentration of the formed succinate. A maximum of $10 \mu \mathrm{M}$ of succinate formed in either the fumarate or malate experiment. However, the specific activity of the succinate is

\section{TABLE V}

Effect of Highly Aerobic Conditions on the Trapping of 2-C ${ }^{14}-$ Acetate Carbon in Fumarate and Malate

\begin{tabular}{|c|c|c|c|c|c|c|c|}
\hline \multirow{2}{*}{ Carrier } & \multirow{2}{*}{ Product } & \multicolumn{2}{|c|}{ Concentration } & \multicolumn{2}{|c|}{ Total activity } & \multicolumn{2}{|c|}{ Specific activity } \\
\hline & & Initial & Final & Initial & Final & Initial & Final \\
\hline & & $\mu \mathrm{Mr}$ & $\mu \mathrm{MI}$ & C.P.M. & C.P.M. & $\underset{\text { PEB } \boldsymbol{\mu M N}}{\text { C.P.M }}$ & $\begin{array}{l}\text { C.P.M. } \\
\text { PER } \mu \mathrm{M}\end{array}$ \\
\hline No carrier added... & $\begin{array}{l}\text { Acetate } \\
\text { "Non-volatile } \\
\text { ether-soluble } \\
\text { material" } \\
\text { Cells } \\
\text { Carbonate }\end{array}$ & 217 & 100 & $\begin{array}{c}74,000 \\
0\end{array}$ & $\begin{array}{r}27,000 \\
1,950 \\
\\
7,710 \\
30,000\end{array}$ & 341 & 271 \\
\hline Fumarate. & $\begin{array}{l}\text { Acetate } \\
\text { Fumarate } \\
\text { Succinale* } \\
\text { Cells } \\
\text { Carbonate }\end{array}$ & $\begin{array}{c}217 \\
250 \\
0\end{array}$ & $\begin{array}{r}61 \\
175 \\
10\end{array}$ & $\begin{array}{c}74,000 \\
0 \\
0\end{array}$ & $\begin{array}{r}10,450 \\
10,000 \\
8,800 \\
4,073 \\
7,128\end{array}$ & 341 & $\begin{array}{r}171 \\
57 \\
880\end{array}$ \\
\hline Malate. & $\begin{array}{l}\text { Acetate } \\
\text { Malate } \\
\text { Sucinate* } \\
\text { Cells } \\
\text { Carbonate }\end{array}$ & $\begin{array}{c}217 \\
250 \\
0\end{array}$ & $\begin{array}{r}94 \\
180 \\
\sim 8\end{array}$ & $\begin{array}{c}74,000 \\
0 \\
0\end{array}$ & $\begin{array}{r}21,050 \\
6,000 \\
4,000 \\
3,065 \\
13,016\end{array}$ & 341 & $\begin{array}{r}223 \\
33 \\
500\end{array}$ \\
\hline
\end{tabular}

Total volume of reactants $20 \mathrm{ml}$. Each tube contained in addition to the 2 - $\mathrm{C}^{14}$-acetate and carriers, $3 \mathrm{ml}$. of phosphate buffer, $\mathrm{pH} 7.0(0.2 \mathrm{M})$ and $3 \mathrm{ml}$. of a 20 per cent suspension of freshly harvested acetate-grown $E$. coli. The reaction mixture was aerated for 4 hours, with tank $\mathrm{O}_{2}$ at room temperature.

* Formed during the course of reaction.

much higher than that of either of the other two $\mathrm{C}_{4}$-dicarboxylic acids and this would be expected if succinate is the precursor of these acids (7).

\section{DISCUSSION}

The results cited in the previous section show quite unambiguously that all components of the Thunberg-Knoop cycle can participate in the oxidation of acetate carbon and confirm the rapid and quantitative entrapment of acetate carbon in succinate as an early step in the reaction sequence. As remarked previously (1) the identity of the first $\mathrm{C}_{4}$ condensation product with succinate is a reasonable assumption strongly indicated by the quantitative data obtained 
in these researches, although other condensation products such as those which might arise from $\mathrm{C}_{2}$ fragments more oxidized than acetate might be involved which are brought into rapid equilibrium with succinate. It will be noted that in some instances an appreciable fraction of the $\mathrm{C}^{14}$ content in the non-volatile fractions was not accounted for as succinate, malate, or fumarate when malate and fumarate were added as carriers.

The finding that $\alpha$-ketoglutarate as a member of the conventional tricarboxylic acid cycle does not enter into equilibria involved in acetate oxidation by adapted strains of $E$. coli is confirmed in these researches. Thus, it appears that only the $\mathrm{C}_{4}$-dicarboxylic acids and pyruvate intervene in the oxidation of acetate by acetate-adapted intact $E$. coli.

It is of interest to examine briefly other possible explanations for the results found in this research. Thus, one might suppose that oxidation proceeds first by direct conversion of acetate to glycolate and thence to glyoxylate which has been suggested by Tolbert $e t a l$. (8), to be involved in a $C_{2}-C_{2}$ condensation to a compound like dihydroxymaleic acid.

Such a mechanism is more attractive to chemists than the direct oxidative condensation of acetate to succinate because it involves the well known aldol type of condensation. However, if the glyoxylic condensation mechanism is operative, it is necessary to assume that, despite the aerobic conditions maintained and over-all removal of hydrogen, there are hydrogen donors present in sufficient quantity and potential to reduce the oxidized $\mathrm{C}_{4}$ intermediate quantitatively to succinate, so that all labeled carbon trapped is recovered in succinate. It is further implied that the presence of large quantities of carrier succinate forces the metabolism to proceed via succinate and thence through the usual $\mathrm{C}_{4}$-acid cycle, whereas in its absence the cycle involved only more oxidized components stemming from a hypothetical intermediate like dihydroxymaleic acid. It must be admitted that some of the present data do not exclude these possibilities. The Warburg experiments on the metabolism of fumarate, malate, and oxalacetate in $E$. coli show that considerable succinate can be formed even from oxalacetate, despite simultaneous oxidation of acetate and $\mathrm{C}_{4}$-dicarboxylic acids. However, and this is perhaps the most significant datum in this paper, under extreme aerobiosis, the reduction of $\mathrm{C}_{4}$-dicarboxylic acid products of succinate oxidation back to succinate is reduced, thus minimizing the possibility of glycolate or glyoxylate being involved as intermediates in acetate oxidation by $E$. coli.

I am indebted to Mr. Donald T. O. Wong for aid in a number of these experiments.

SUMMARY

1. Simultaneous oxidation of $\mathrm{C}^{14}$-methyl-labeled acetate, and unlabeled malate or fumarate and $\alpha$-ketoglutarate results in entrapment of labeled carbon 
in the $\mathrm{C}_{4}$-dicarboxylic acids, but not in $\alpha$-ketoglutarate, although all substrates are utilized at comparable rates.

2. A large endogenous reduction of all $\mathrm{C}_{4}$-dicarboxylic acids (fumarate, oxalacetate, and malate) to succinate is observed under aerobic conditions, and when vigorous oxidation is proceeding. This effect occurs with both freshly harvested young (18 hour) cells and stored ( 2 week) cells.

3. This reduction can be considerably minimized under high oxygen tensions.

4. The quantitative concordance of these results with a Thunberg-Knoop cyclic mechanism for acetate oxidation is shown. Possible alternative $\mathrm{C}_{4}$ products formed prior to succinate are not completely excluded, but it appears that the cells can utilize the succinate condensation as a major pathway in acetate oxidation.

\section{BIBLIOGRAPHY}

1. Ajl, S. J., and Kamen, M. D., J. Biol. Chem., 1951, 189, 845.

2. Ajl, S. J., J. Bact., 1950, 69, 499.

3. Lugg, J. W. H., and Overell, B. T., Australian J. Sc., 1948, 1, 98.

4. Korkes, S., and Ochoa, S., J. Biol. Chem., 1948, 176, 463.

5. Harrison, J., Biochem. J., 1939, 33, 1466.

6. Krebs, H. A., Biochem, J., 1937, 31, 2095.

7. Zilversmit, D. B., Entenman, C., and Fishler, M. C., J. Gen. Physiol., 1943, 26, 325.

8. Tolbert, N. E., Clagett, C. O., and Burris, R. H., J. Biol. Chem., 1949, 181, 905. 